\title{
Cation Exchange Capacity in Mirador and Misoa Formation and the Effect in Enhanced Oil Recovery
}

\author{
Victoria Mousalli ${ }^{1,2}$, Johnny Bullón ${ }^{1}$, Franklin Salazar ${ }^{1}$ \\ ${ }^{1}$ Laboratorio FIRP, Universidad de los Andes, Mérida, Venezuela \\ ${ }^{2}$ Escuela de Ingeniería Geológica, Universidad de los Andes, Mérida, Venezuela \\ Email:mousalliv@gmail.com
}

\begin{abstract}
In the Enhanced Oil Recovery (EOR) methods, particularly in surfactant flooding, many tests have been performed, many scientific papers have been written and many findings have been found; however, there are still a lot of questions without any answers. Some of them are the interactions between the different reservoir components and the chemical flooding that are used in the EOR process. Nowadays, the main problem in the petroleum industry is the economic feasibility. Some authors report that the surfactant lost by the adsorption in the porous media increases the amount of surfactant that is needed. Understanding and controlling the amount of surfactant adsorbed directly, affects the project economics. It is crucial to the economic success of an EOR project that adsorption is reduced in the project design; to do so it requires an understanding of surfactant adsorption mechanisms. One of the factors that affect the surfactant adsorption in porous media is the mineralogy of the reservoir by the Cation Exchange Capacity (CEC) due to clays minerals present in the mineral composition of the reservoir.

The Mirador and Misoa formations are the reservoirs that have the most important oil reserves in the western of Venezuela. In this investigation, the main objective was to know the relation between the mineral composition and the CEC of this geological formations and how this can affect the EOR. The methodology consists in pulverizing and filtering some samples of the both formations, after that a DRX analysis was made in order to obtain the mineral phases present. The results corroborate that Quartz is the main mineral present with more than $90 \%$, but in the Mirador Formation, it has approximately $8 \%$ of clay minerals like Kaolinite, Illite and 0,3\% of dolomite mineral unlike samples of Misoa that contain 98\% of Quartz. The results of Cation exchange obtained from atomic absorption spectrephotometry, the Misoa Formation exhibit the major CEC versus Mirador CEC, using the $\mathrm{Mg}, \mathrm{Ca}, \mathrm{K}$, cation, this indicate that the presence of the clay minerals, especially Montmorillonite, kaolinite and Illite, control the CEC in the porous media. This phenomenon is explained by the crystalline structure of the clay mineral that shows the 1:1-layer structure (kaolinite) that consists of the repetition of one tetrahedral and one octahedral sheet, while in the 2:1-layer structure (Illite) one octahedral sheet is between two tetrahedral sheets. When the tetrahedral and octahedral sheets are joined in a layer, the resulting structure can be either electrically neutral or negatively charged, but it depends on a number of factors such as $\mathrm{pH}$, ionic strength, temperature and pressure. It's important to know the mineral composition of the reservoir, mainly the clays minerals, that affect directly over the surfactant adsorption by the CEC, kaolinite (1:1 T-O-T structure) has the lower CEC 3-5 meq/100gr, and Illite 10-50 meq/100gr, (2:1 structure) and the charge of these minerals is negative.
\end{abstract}

Keywords: Asorption, Enhaced Oil Recovery, Surfactants.

\section{Capacidad de intercambio catiónico en las formaciones Mirador y Misoa y el efecto en la recuperación de petróleo mejorada}

\section{Resumen}

En los métodos de recuperación mejorada de petróleo, por sus siglas en inglés (EOR), específicamente en inyección de surfactantes, se han realizado muchas pruebas, se han escrito documentos científicos y se han encontrado descubrimientos, pero hay muchas preguntas sin respuestas. Algunas de ellas son las interacciones entre los diferentes componentes del depósito y las formulaciones químicas que se utilizan en el proceso EOR. Ahora, el principal problema en la industria petrolera actual es la viabilidad económica, y algunos autores informan que el surfactante perdido por la adsorción en los medios porosos aumenta la cantidad de surfactante que se necesita. Comprender y controlar la cantidad de surfactante adsorbido afecta directamente la economía del proyecto. Es crítico para el éxito económico de un proyecto EOR que la adsorción se minimice en el diseño

Cita: Mousalli, V., Bullón, J. y Salazar, F. (2020). Cation Exchange Capacity in Mirador and Misoa Formation and the Effect in Enhanced Oil Recovery. Revista Fuentes: El reventón energético, 18(1), 31-40. 
del proyecto; para hacerlo requiere una comprensión de los mecanismos de adsorción de los surfactantes. Uno de los factores que afectan la adsorción de surfactante en medios porosos es la mineralogía del reservorio por la capacidad de intercambio de cationes (CEC, por sus siglas en inglés) debido a los minerales arcillosos presentes en la composición mineral del reservorio.

Las formaciones Mirador y Misoa son los reservorios que tienen las reservas de petróleo más importantes en el oeste de Venezuela. En esta investigación, el objetivo principal fue conocer la relación entre la composición mineral y el CEC de estas formaciones geológicas y cómo esto puede afectar el EOR. La metodología consiste en pulverizar y filtrar algunas muestras de ambas formaciones, luego se realizó un análisis DRX para obtener las fases minerales presentes. Los resultados confirman que el Cuarzo es el principal mineral presente con más del 90\%, pero en la Formación Mirador tiene aproximadamente un $8 \%$ de minerales arcillosos como caolinita, illita y $0,3 \%$ de mineral de dolomita a diferencia de las muestras de Misoa que contienen 98\% de Cuarzo. Los resultados del intercambio de cationes obtenidos por espectrofotometría de absorción atómica, la Formación Misoa exhiben el CEC principal versus CEC de Mirador, utilizando el catión Mg, Ca, K, esto indica que la presencia de minerales de arcilla, especialmente montmorillonita, caolinita e illita, controla La CCA en los medios porosos. Este fenómeno se explica por la estructura cristalina del mineral de arcilla que muestra la estructura de capa 1: 1 (caolinita) que consiste en la repetición de una lámina tetraédrica y una octaédrica, mientras que en la estructura de capa 2: 1 (illita) una lámina octaédrica se encuentra entre dos láminas tetraédricas. Cuando las láminas tetraédricas y octaédricas se unen en una capa, la estructura resultante puede ser eléctricamente neutra o con carga negativa, pero depende de algunos factores como el $\mathrm{pH}$, la fuerza iónica, la temperatura y la presión. Es importante conocer la composición mineral del reservorio, principalmente los minerales de arcillas, que afectan directamente sobre la adsorción de surfactante por el CEC, la caolinita (estructura TOT 1: 1) tiene el CEC más bajo 3-5 meq / 100gr, y Illite 10- 50 meq / 100gr, (estructura 2: 1) y la carga de estos minerales es negativa.

Palabras clave: Adsorción, Recuperación Mejorada de Petróleo, Surfactantes.

\section{Introduction}

The Enhanced Oil Recovery (EOR) has variables that can influence the success of this method. One of them used recently is the surfactant flooding; surfactants can act in several ways to enhance oil production. For example, by reducing the interfacial tension between oil trapped in small capillary pores and the water surrounding those pores, thus allowing the oil to be mobilized (Toro et al, 2018; Aya et al, 2018).

In selecting a suitable surfactant for any EOR application, one of the criteria for economic success is minimizing surfactant loss to adsorption in the porous media. Factors affecting surfactant adsorption include temperature, $\mathrm{pH}$, salinity, type of surfactant and types of solids found in the reservoir (Martin \& Páez, 2017; Jaimes et al, 2019). Generally, the only factor that can be manipulated for EOR is the type of surfactant to be used; the other factors are determined by reservoir conditions (Taber et al, 1997 in Schramm 2000).

The adsorption is a spontaneous process where each surfactant molecule is adsorbed in the porous media depending on the surface charge, which is the main problem in the EOR. Many surfactants adsorb onto a solid due, in a large part, to the electrostatic interactions between charged sites on the solid surface and the charged headgroups of the ionic surfactants, this interaction can be consequence of the Cation Exchange Capacity (CEC) that is the summary of all exchange cations that a mineral can adsorb influenced by the $\mathrm{pH}$ (Ordoñez \& Garcia, 2015). The oil reservoir contains many minerals that can increase or decrease the amount of surfactant that have lost by adsorption, for example, the clay minerals like kaolinite, Illite and montmorillonite.

The CEC varies between the different clays minerals, and is directly affected with the structural features (crystalline structure), $\mathrm{pH}$, and surface area. In the 1:1 (T-O) structure, it is supported by hydrogen bridges between $\mathrm{OH}$ groups of the octahedral sheets and the $\mathrm{O}_{2}$ of the tetrahedral sheets, this bond is strong enough and can support the global structure of the mineral and avoid the cations to access between the sheets. By the other hand, the 2:1 (T-O-T) structure, the bonds are not possible because one tetrahedral sheet is in front of another tetrahedral sheet, this configuration is electrically compensated by entering cations like Potassium in the Illite clay, and water molecule in the Montmorillonite clay. In the Table 1, the main physicochemical property of clays is observed.

Table 1. Comparative chart of physicochemical property of clays. Look for the values in the article.

\begin{tabular}{|l|c|c|c|}
\hline Clay Minerals & $\begin{array}{c}\text { Crystalline } \\
\text { Structure }\end{array}$ & $\begin{array}{c}\text { CEC } \\
(\mathbf{m e q} / \mathbf{1 0 0 g})\end{array}$ & $\begin{array}{c}\text { Surface } \\
\text { area* }(\mathbf{m} / \mathbf{g})\end{array}$ \\
\hline Kaolinite & T-O & $3-3,7 * *$ & $14-23$ \\
\hline Illite & T-O-T & $15 * * *$ & $76-91$ \\
\hline Montmorillonite & T-O-T & $60-120 * *$ & $600-750$ \\
\hline
\end{tabular}

*Diamond and Kinter (s.f) **Borden and Giese (2001) ***Srondon et al (1986). 
The elementary character is the $\mathrm{SiO}$ tetrahedral linkage of an essentially two-dimensional, hexagonally symmetric, network. One side of this "sheet" network is coordinated with other cation-oxygen complexes joined by an important component covalent bonding while the other is coordinated by essentially ionic bonding or van der Waals type bonds. The key to phyllosilicate structures is the oxygen network which determines the shape and extent of the structure (Velde, 1977).

In clay minerals the most common exchangeable cations, in order of usual relative abundance, are $\mathrm{Ca} 2+$, $\mathrm{Mg} 2+, \mathrm{H}+, \mathrm{K}+, \mathrm{NH} 4+{ }^{\prime} \mathrm{Na}+$ (Grim, 1968). A superficial classification of the most common clay mineral groups can be based upon the number of ions present in the octahedral layer (2 diocatahedral or 3 trioctahedral) and the numbers and the kind of ions present between the basic sheet structures (interlayer ions) which are ionically bonded to the oxygen networks. See Table 2.

Table 2. Relationship between Interlayer charge and crystalline structure of some clays minerals.

\begin{tabular}{|c|c|c|c|c|}
\hline Clay mineral & 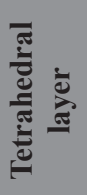 & 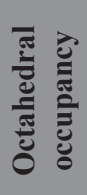 & 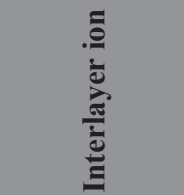 & 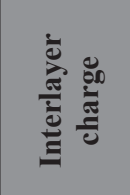 \\
\hline Kaolinite & 1 & 2 & 0 & 0 \\
\hline Illite & 2 & 2 & $\mathrm{~K}$ & $0,7-1$ \\
\hline $\begin{array}{l}\text { Montmorillonite } \\
\text { (trioctahedrical) }\end{array}$ & 2 & $2,7-3$ & $\mathrm{Na}, \mathrm{K}, \mathrm{Ca}, \mathrm{Mg}$ & $0,25-0,60$ \\
\hline $\begin{array}{l}\text { Montmorillonite } \\
\text { (dioctahedrical) }\end{array}$ & 2 & 2 & $\mathrm{Na}, \mathrm{K}, \mathrm{Ca}, \mathrm{Mg}$ & $0,25-0,60$ \\
\hline
\end{tabular}

Source: Velde (1977).

In the cases where cations are bonded in ionic coordination to the oxygen nets (interlayer ions), the negative attractive charge arises from substitution in either the tetrahedral or octahedral coordinated positions. The substitutions increase the net negative charge for the whole 2:1 structure and, since the oxygen network is fixed in kind and quantity, this charge imbalance is satisfied by the addition of predominantly ionically bonded cations in the interlayer position. The basic 2:1 network contains $\mathrm{O}_{10}(\mathrm{OH})_{2}$, the hydroxyls are in coordination uniquely with the octahedral ions. The negative charge is -22 . It is important to note that the clay minerals which have an interlayer charge between 1.0 and 0.7 contain almost exclusively potassium as an interlayer ion. In minerals with a lower charge $0.6-0.25$ a large charge is less, no alkali or alkaline earth elements are present. Expanding phases are those minerals with an interlayer charge between about 0.6 and 0.25 ; such minerals can easily accept various combinations of ions and polar molecules in the interlayer position.

In this investigation, the samples used correspond to Mirador and Misoa formations, the first one is a clastic oil reservoir of Maracaibo Lake Basin, Venezuela, and the second one has the most important reserves of hydrocarbons of the western of Venezuela, and contains $70 \%$ of the oil reserves. The main mineral composition of both formations is basically quartz, feldspars and clays minerals. In the Misoa Formation two outcrops were analyzed and in the Mirador Formation one outcrop, both were made petrography analysis, DRX analysis, isoelectric point measure, surface area and particle size.

\section{Experiment}

Materials. Samples of Misoa and Mirador Formations, The specific surface area measured by the BET method was $0,92 \mathrm{~m} 2 / \mathrm{g}$ for Misoa Formation and 1,69 m2/g to Mirador Formation. For Mirador formation X-ray diffraction (XRD) it was made it by a Siemens D5005 difractometer equipped, with a A-Ray tube with coper radiaton (CuKalfa); the final analysis yielded, the following mineralogical data: $91,90 \mathrm{wt} \%$ quartz, 7,40 $\mathrm{wt} \%$ kaolinite, $0,30 \mathrm{wt} \%$ dolomite, and $0,70 \mathrm{wt} \%$ illite. For Misoa Formation 98,5 wt $\%$ quartz, 0,8 wt $\%$ kaolinite, $0,70 \mathrm{wt} \%$ montmorillonite. By petrographic analysis the samples of Mirador and Misoa formations (Figure 1) were classified like quartzarenite by Mineral-Based Classification of Sedimentary Rocks by Folk (1974).

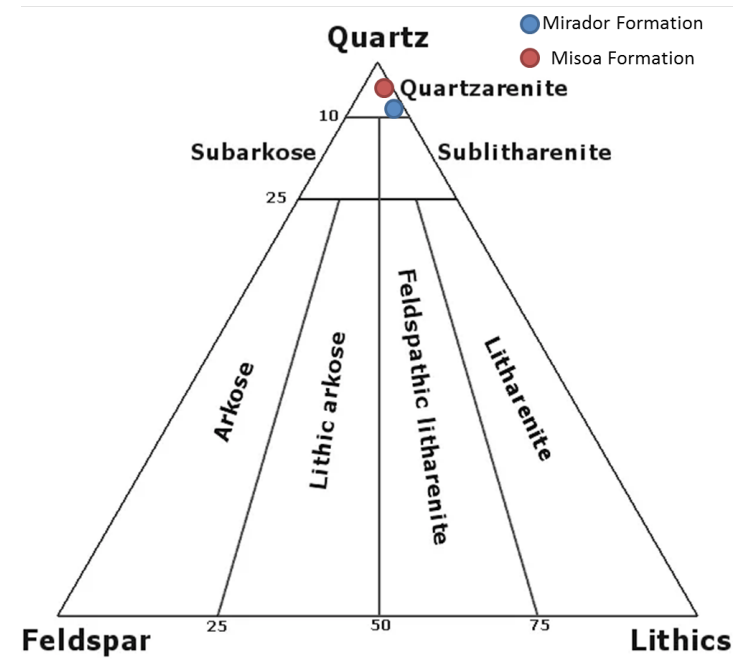

Figure 1. Mineral-Based Classification of Sedimentary Rocks by Folk (1974). 
Solutions. A $1 \mathrm{wt} \%$ of $\mathrm{NaCl}$ in distilled water and distilled water was used in the experiments for washing rocks samples.

\section{Methods}

Step 1. Mirador Formation samples were obtained in one outcrop in "La Roca" área, Zea road Merida-Venezuela, (N 08 $28^{\prime}$ 14", E $67^{\circ} 30^{\prime}$ 08) Misoa Formation samples were took in two outcrops in Agua Viva, road (outcrop 1: N 1059313 y E 02321965, outcrop 2: N 1059252 y E 0322446).

Two samples of $5 \mathrm{grs}$ each formation were pulverized and prepared for measured of particle size (Laser Diffraction Particle Size Analyzer of Beckman Coulter) and surface area (Mastersizer 2000 of Malver).

Step 2. The samples of both formations were washed (solid/liquid relation 5:40) with $1 \mathrm{wt} \% \mathrm{NaCl}$ solution each 24 hours per 7 days, after that, were washed with distill water each 24 hours per 4 days, the liquid recollected for each one was labeled separately.

Step 3. Were measured the CEC with Bruker FTIR Spectrofotometer, Tensor 27 model, with ATR adaptor (attenuated total reflectance) Miracle model of Pike Technologies, in both formations by atomic absorption spectrephotometry for the cations $\mathrm{K}, \mathrm{Ca}, \mathrm{Mg}$ in 11 samples of Misoa Formation and 11 samples of Mirador Formation of remains solution.

\section{Results and discussion}

\section{Particle size, Surface area and Mineral Composition}

The clay minerals are not the only components having CEC; all minerals of extremely small particle size have a small CEC as a result of broken bonds around their edges. This capacity increases as the particle size decreases, but even at the smallest size in which nonclay minerals occur associated with clays, the exchange capacity due to broken bonds is relatively insignificant (Grim (1968) in Ma et al, 1999).

The surface area is a particular value that can modify the CEC, the relation between structure and surface area indicates that the kaolinite has a minor surface area as it has a simply crystalline structure 1:1 type, and the montmorillonite has the major surface area because it has a crystalline structure 2:1 type, almost the particle size can affect the surface area too. For example, if the minor particle size is the major surface area, like it's shown in the Figure 2.
In case of the Mirador and Misoa formations the surface area is related directly with their mineral composition, and particle size, for example, the first one has a minor particle size approximately $7 \mu \mathrm{m}$ and its surface area is less than the second one that has the major particle size approximately $18 \mu \mathrm{m}$. Additionally, the particle size is related to the minerals composition because the Misoa Formation has de major percentage of quartz than Mirador formation that has the major percentage of clay minerals. Table 3 and Table 4.

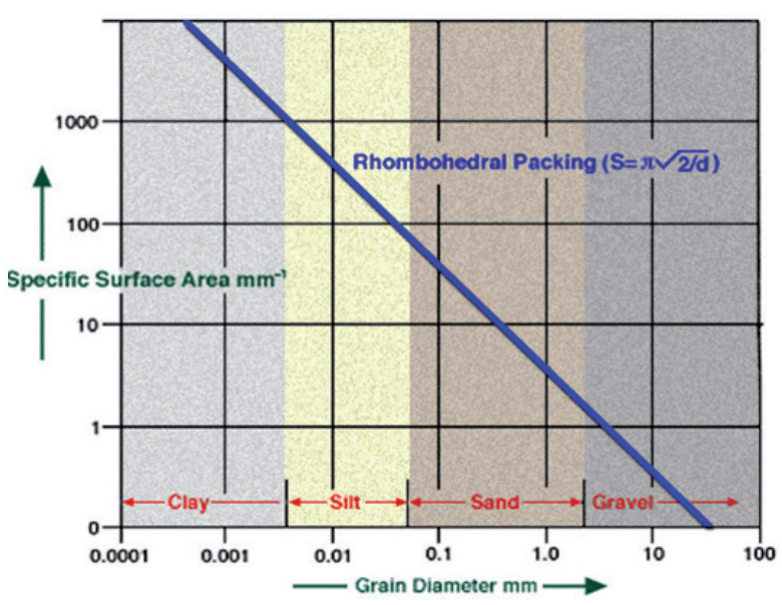

Figure 2. Generalizes the relationship between grain size and grain surface area. Source: https://www.ihrdc.com/els/ipimsdemo/t26/offline_IPIMS_s23560/resources/data/G4107.htm.

Table 3. Values of Particle size and Surface area in Mirador and Misoa formations.

\begin{tabular}{|c|c|c|}
\hline Formation & Particle size & Surface area \\
\hline Misoa & $17,8 \mu \mathrm{m}$ & $0,92 \mathrm{~m}^{2} / \mathrm{gr}$ \\
\hline Mirador & $6,57 \mu \mathrm{m}$ & $1,69 \mathrm{~m}^{2} / \mathrm{gr}$ \\
\hline
\end{tabular}

Quartz is the strongest mineral that can be composed several sedimentary rocks and oils reservoirs, and provides its hardness to be broken in smaller pieces, by mechanical methods. If the mineral composition of the reservoir has highest percentages of quartz, like Misoa formation, is normal that the particle size as well as surface area can be affected.

The surface area is related with the crystalline structure of the minerals that compounds the formations. For example, the clays mineral has highest surface area because their structures are in sheet form, this peculiarity provide a special crystalline form in addition to be a charge surface. 
Table 4. DRX Results of Mirador and Misoa Formations.

\begin{tabular}{|l|c|c|}
\hline \multicolumn{1}{|c|}{ Minerals } & $\begin{array}{c}\text { Misoa } \\
\text { Formation }\end{array}$ & $\begin{array}{c}\text { Mirador } \\
\text { Formation }\end{array}$ \\
\hline Quartz & $98,50 \%$ & $91,90 \%$ \\
\hline Illite & 0 & $0,70 \%$ \\
\hline Kaolinite & $0,80 \%$ & $7,40 \%$ \\
\hline Montmorillonite & $0,70 \%$ & 0 \\
\hline Dolomite & 0 & $0,30 \%$ \\
\hline
\end{tabular}

The common existence of kaolinite (see Figure 3) in the sedimentary formations especially in reservoirs rocks Mirador and Misoa formations and its autogenic formation indicates that it frequently remains stable at depth. During the burial of a sedimentary series and their subsequent diagenesis or metamorphism, kaolinite disappears from the clay mineral parageneses for different reasons; combination with $\mathrm{Mg}$ from destabilized dolomite, combination with other phases to produce illite-chlorite or mixed layered minerals or by combination with quartz to produce pyrophyllite (Velde, 1977).

Kaolinite is a frequent product of hydrothermal alteration, commonly associated with mica or expanding phases in the "argilic" type alterations. These studies indicate that kaolinite can be formed by hydrothermal alteration at the surface as well as to depths of several kilometers.

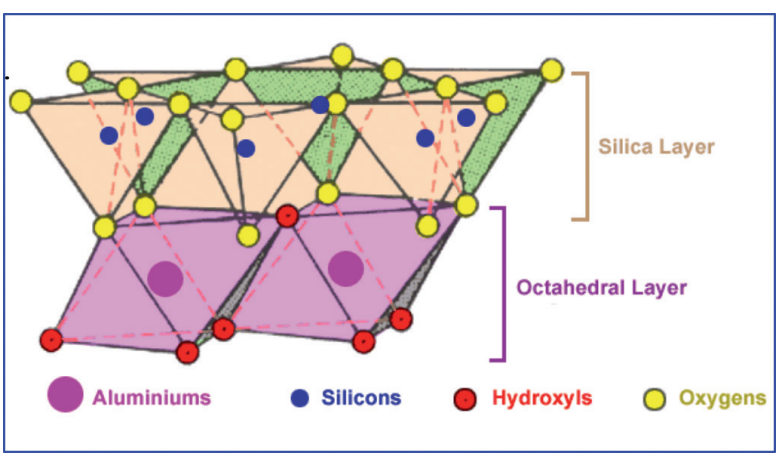

Figure 3. Crystalline structure of Kaolinite (T-O)

Source: https://www.ihrdc.com/els/ipims-demo/t26/offline IPIMS_s23560/resources/data/G4105.htm.

Among the neutral-lattice phyllosilicates only kaolinite is an important constituent of sediments, sedimentary rocks and hydrothermal alterations. Its presence in sedimentary rocks indicates most likely quite alkaline conditions. This leaves kaolinite as the only important neutral-lattice mineral in clay assemblages.
The Illite represents (see Figure 3), the dominantly potassic, dioctahedral, aluminous, mica-like fraction of clay-size materials. The low potassium aluminous mica-like mineral can form diagenetically, also appears to be the early product of weathering in cycles intense alteration or one of the stable products under intermediate conditions. Thus detrital sediments can contain illite of at least four origins; material crystallized during weathering reconstituted degraded mica, detrital mica formed at high temperatures and of course unaffected detrital illite from sedimentary rocks.

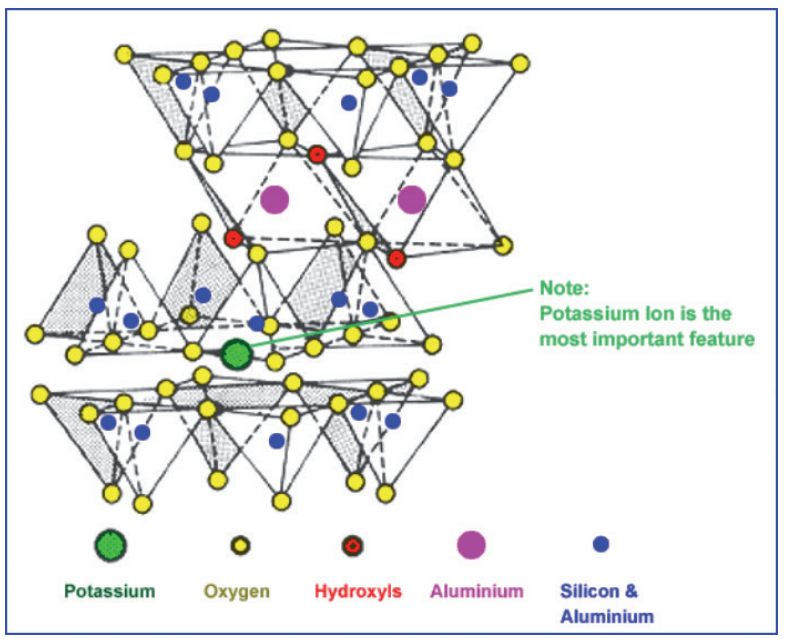

Figure 4. Crystalline structure of Illite (T-O-T).

Source: https://www.ihrdc.com/els/ipims-demo/t26/offline IPIMS_s23560/resources/data/G4105.htm.

During the process of lithification and deep burial, illite appears to remain stable or at least slow to react with other minerals. Being by far the most dominant species clay mineral in argillaceous sedimentary rocks (Grim, 1968; Millot, 1964).

If then illite, or a potassic, mica-like mineral, is present in most of the geologic environments, the variations of its structure and chemistry must be examined carefully in order to establish its chemical stability relative to the system in which it is found (Velde, 1977).

The main features of their formulas are traditionally compared to muscovite, the mineral closest to illite compositions. This clay mineral does not have a total lattice charge equal to 1.00 , and the total silica ions in the tetrahedral sites exceeds 3.00. The charge, distributed between 3 octahedral and tetrahedral sites, is usually compensated by potassium and sodium ions, more questionably by $\mathrm{Ca}^{2+}$ or $\mathrm{H}_{3} \mathrm{O}^{+}$. 
Montmorillonite is composed of units made up of two silica tetrahedral sheets with a central alumina octahedral sheet. The tetrahedral and octahedral sheets combine in such a way that the tips of the tetrahedra of each silica sheet and one of the hydroxyl layers of the octahedral sheet form a common layer (see Figure 4).

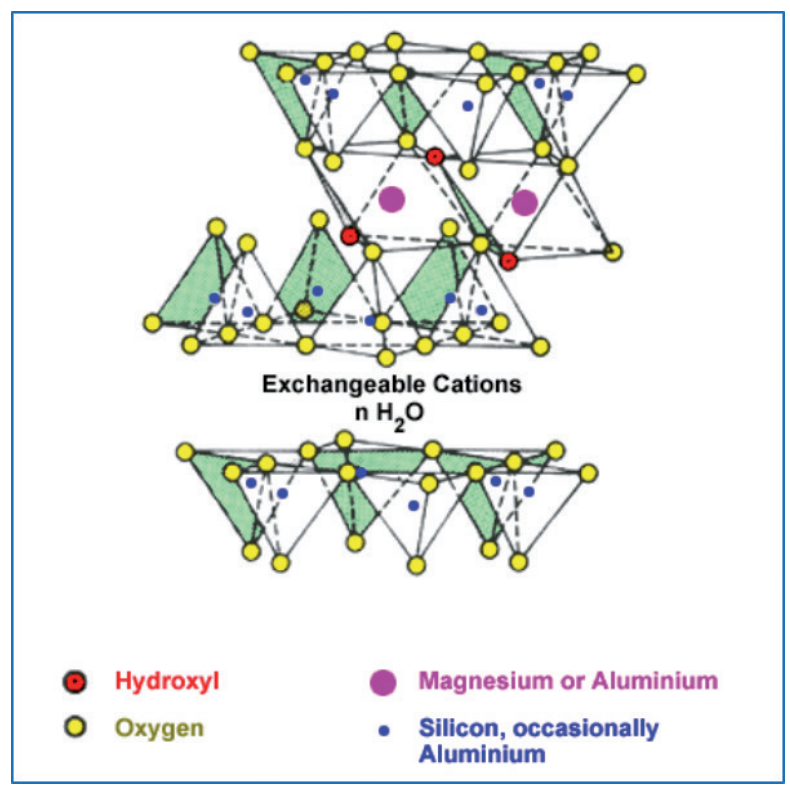

Figure 5. Crystalline structure of Montmorillonite (T-O-T) Source: https://www.ihrdc.com/els/ipims-demo/t26/offline IPIMS_s23560/resources/data/G4105.htm.

The silica-alumina-silica units are continuous in the ' $a$ ' and ' $b$ ' crystallographic directions and are stacked one above the other in the ' $c$ ' direction. The ' $c$ ' axis spacing also varies with the nature of the interlayer cations present between the silicate layers (Gopal et al, 2008).

The resulting negative net charge is balanced by exchangeable cations adsorbed between the unit layers and around their edges.

Montmorillonites (dioctahedral) are very common in sequences of sedimentary rocks, like reservoir rocks, especially in younger sediments found near the surface. Some authors in Velde (1977) proposed that the conversion of montmorillonite to other minerals in sequences of deeply buried sedimentary rocks is independent of time or geologic age and appears to be a function of the geothermal gradient which the rocks have experienced. These studies indicate that fully expandable dioctahedral montmorillonite is not stable above $100^{\circ} \mathrm{C}$ at depths of two kilometers or more.

\section{Cationic Exchange Capacity}

In this research, the CEC was measured and studied in two geological formations. It is necessary to acknowledge that the principal components that can adsorb and affect the efficiency of EOR are the clay minerals constituents in the reservoir like kaolinite, illite and montmorillonite, which are present in the DRX analysis of Misoa and Mirador Formations.

Clay minerals have the property of absorbing certain ions and retaining them in an exchangeable state. The most common exchangeable cations, in order of usual relative abundance, are $\mathrm{Ca}^{2+}, \mathrm{Mg}^{2+}, \mathrm{H}^{+}, \mathrm{K}^{+}, \mathrm{NH}^{+} \mathrm{Na}^{+}$. (Grim, 1968 in Ma et al, 1999). For this investigation, it was measured $\mathrm{Ca}^{2+}, \mathrm{Mg}^{2+}$, and $\mathrm{K}^{+}$.

It is commonly believed that cation exchange occurs due to the broken bonds around the crystal edges, the substitutions within the lattice, and the hydrogen of exposed surface hydroxyl that maybe exchanged.

The clay minerals are not the only components having CEC. All minerals of extremely small particle size have a small CEC as a result of broken bonds around their edges. This capacity increases as the particle size decreases, but even at the smallest size in which nonclay minerals occur associated with clays, the exchange capacity due to broken bonds is relatively insignificant (Grim, 1968 in Ma et al, 1999).

The difference in the contents of clay minerals between both formations affects not only the value of surface area; in fact, it affects the total and individual CEC. Because this parameter is controlled by the charge of the clay surface and $\mathrm{pH}$. For example, some researcher support that the kaolinite has the isoelectric point near to the $\mathrm{pH} 5$, in values greater than this the surface charger is negative, below this, it is positive charged. By the other hand, illite and montmorillonite don't have this quality even if the $\mathrm{pH}$ is acid or not, the charge is always negative.

This is consequence of the crystalline structure of the clays mineral, for example, the 1:1 layer structure (kaolinite) that consists of the repetition of one tetrahedral and one octahedral sheet, while in the 2:1 layer structure (Illite) one octahedral sheet is sandwiched between two tetrahedral sheets, when the tetrahedral and octahedral sheets are joined in a layer, the resulting structure can be either electrically neutral or negatively charged. 
The results of the atomic absorption by spectrophotometry shows a very interesting behavior, as you can see in Table 3.

Table 3. CEC results of Mirador and Misoa Formation.

\begin{tabular}{|l|c|c|}
\hline & \multicolumn{2}{c|}{ Cation Exchange Capacity (meq/gr) } \\
\hline Cation & Mirador Formation & Misoa Formation \\
\hline $\mathrm{Ca}$ & 0,0032 & 0,0096 \\
\hline $\mathrm{Mg}$ & 0,0055 & 0,0022 \\
\hline $\mathrm{K}$ & 0,0011 & 0,0022 \\
\hline Total CEC & 0,0098 & 0,0140 \\
\hline
\end{tabular}

The results for both formations can be interpreted together or individually. In case of Mirador Formation show major value of CEC for $\mathrm{Mg}$ and minor for $\mathrm{K}$. It is due to the presence of dolomite in the mineral composition of this formation, which can contribute the cation from its structure. For $\mathrm{Ca}$ and $\mathrm{K}$ cation the CEC confirm the order of exchangeable cations propose by Grim (1968) in Ma et al, 1999. By the other hand is important to emphasize that the clay minerals percentage for this formation is about $8 \%$, the principal mineral is kaolinite with $7 \%$.

Some authors (Ma and Eggleton, 1999) refers that the kaolinite CEC is almost entirely caused by surface charge; and structural substitution is minor, generally contributing $<5 \%$ of the total CEC. In addition, they propose that the CEC of kaolinite strongly depends on the particle size and $\mathrm{pH}$ value.

The CEC values showed by Misoa Formation samples indicate a major $\mathrm{CEC}$ for $\mathrm{Ca}$ cation, $\mathrm{Mg}$ and $\mathrm{K}$, and correspond with the content of clay minerals; the main is montmorillonite, which has the highest surface area and CEC of the three principal clay minerals in reservoir rocks. In the montmorillonite structure, interlayer swelling occurs when it is exposed to water. The swelling procedure depends on valences and atomic radii of the exchangeable cations. Cation exchange studies on montmorillonites have shown a number of interesting relations regarding ionic distribution between aqueous solutions and the silicate.

Now, the total CEC calculated for the three exchangeable cations $\mathrm{Ca}, \mathrm{Mg}$ y $\mathrm{K}$ measured, for each formation indicate that the Mirador formation has minor value, due to the mineral composition and specifically the type of clay minerals that it is shown in the DRX analysis. But the CEC of Mg in Mirador Formation is major that the Misoa Formation, because the presence of dolomite mineral, that can be exchange this cation easily and it is classified like a carbonate mineral group.

In case of $\mathrm{K}$ and $\mathrm{Ca}$ Misoa has greater $\mathrm{CEC}$ and it is consequence of the montmorillonite clay that it is in the mineral composition, and the highest CEC that it is attributed to clay minerals that has a crystalline structure 2:1 or T-O-T.

\section{Conclusions}

Clays have been good adsorbents because of existence of several types of active sites on the surface, and ion exchange sites, and usually display negative charge in the surface area. The clay minerals are the common components of the clastic oil reservoirs and can affect CEC and the adsorption of surfactant in the porous media by the ionic strength, temperature and pressure.

The surface area depends on the particle size and mineral composition of the reservoir and can modified the CEC value.

The CEC in order of major value is Montmorillonite> Illite > kaolinite and Misoa Formation has major CEC than Mirador Formation, even when have minor clays in the mineralogical composition, but it is provoked by the percentage of montmorillonite.

\section{References}

Ammann, L. (2003). Cation exchange and adsorption on clays and clays minerals. Kiel: Dissertation Submitted for the degree "Dr. rer. nat." of the faculty of mathematics and natural sciences Christian-Albrechts-Universität.

Anjos Barreto, L. (2006). Caracterización sedimentológicade un afloramiento correspondiente a la Unidad Informal B-6 de la Formación Misoa y su correlación con el subsuelo de la Cuenca del Lago de Maracaibo (Carretera El Venado-La Raya, Edo Zulia). Trabajo Especial de Grado para optar al titulo de Ingeniero Geológo. Caracas, Venezuela: Universidad Central de Venezuela.

Arenivar M., B., Martinez P., G., \& Rivera, L. (2012). Evaluación fisicoquímica de arcillas naturales existentes en el Campo Geotérmico de Berlín, Usultán y Elaboración del diagnóstico de su comportamiento reológico durante la perforación de pozos geotrémicos. Trabajo 
de Graduación previo a la opción al Grado de Ingeniero Químico, Universidad de San Salvador, San Salvador.

Arostegui, J., Nieto, F., Ortega-Huertas, M., Velazco, F., \& Zuluaga, M. C. (29 de Noviembre de 1993). Mineralogía de Arcillas y grado de Diagénesis del Cretácico Inferior,en el flaco sur del Anticlinorio de Bilbao. Estudios Geológicos, 49, 277-286.

Avendaño, J. (Marzo de 2008). Influencia del pH en la adsorción de surfactantes catiónicos sobre diversas superficies rocosas. Trabajo para optar al grado de Magíster Scientiae en Ingeniería Química. Merida, Merida, Venezuela.

Aya, C. L. D., Guardia, V. M. D., Toro, G. A. M., García, R. H. C., \& Pérez, H. I. Q. (2018). Metodología para la priorización de tecnologías emergentes de recobro mejorado químico. Revista Fuentes, 16(2).

Barba, F. (1999). Rocas Sedimentarias y facies Sedimentarias: Relaciones conceptuales y genéticas. Aplicaciones didácticas. Enseñanza de las Ciencias de la Tierra, 29-37.

Bergaya, F., \& Lagaly, G. (2013). Handbook of Clay Science. United Kingdom: Elseiver Publications.

Bertolino, S. (2006). Arcillas y Ambientes Sedimentarios. S.C. de Bariloche-Argentina: IV Congreso Latinoamericano de Sedimentologia.

Borden, D., \& Giese, R. (2001). Baseline Studies of the Clay Minerals Society Source Clays:Cation Exchange Capacity Measurments by the Amonian-Electrode Method. Clay and Clays Minerals, 49(5), 444-445.

Cabrera, J., \& La Cruz, S. (Septiembre de 2013). Descripción mineralógica y petrográfica de la Formación Mirador con fines de formulación óptima en Recuperación Mejorada de Petróleo. Trabajofinal para obtener el grado de Ingeniero Geólogo. Mérida, Mérida, Venezuela.

Cornelis, K., \& Cornelius, H. (1960). Manual de Mineralogía de Dana. Barcelona-Buenos Aires-Mexico: Reverté.

Dabrowsky, A. (2001). Adsorption-from theory to practice. Advances in Colloid and Interface Science, 135-224.

Di Michele, F. (2018). Análisis Documental de la Capacidad de Intercambio Catiónico de la Caolinita, Illita y Montmorillonita con fines de Recuperación Mejorada de Petróleo. Universidad de los Andes, Escuela de Ingeniería Geológica. Merida : Universidad de los Andes.

Diamond, S., \& Kinter, E. (s.f.). Surface Areas of Clay Minerals as derived from Measurements of Glycerol Retention. Washington, D.C.: Bureau of Public Roads, Physical Research Division,.

Dominguez Diaz, M. C., Bell Parladé, J. M., Doval Montoya, M., \& García Romero, E. (1997). Análisis de los minerales de arcillas y sus procesos genéticos en las Formaciones Arcillosas de la Cuenca del Tajo. Estudios Geológicos, 53, 185-196.

Francis , C., Bauer, A., Schäfer, T., Griffault, L., \& Lanson, B. (2002). Experimental investigation of the interaction of clays with high $\mathrm{pH}$ solutions: A case study from the CallovoOxfordian formation, Meuse - Haute Marne underground laboratory (France). Clays and Clay Minerals, Clay Minerals Society, 50(5), 633-646.

Fuerstenau, D., \& Pradip. (2005). Zeta potentials in the flotation of oxide and silicate minerals. Advances in Colloid and Interface Science, 9-26.

García Romero, E., \& Suarez Barrios, M. (s.f.). Las Arcillas: Propiedades y Usos. Recuperado el 11 de 02 de 2016, de http://www.uclm.es/users/ higueras/yymm/MarcoNuevo.htm

Gaviria, S., Sarmiento, G., \& Sánchez, M. (2013). Minerales Arcillosos Marcadores de Procesos Termodinámicos en Niveles Lodolíticos del Cretáceo Inferior, Región de Ráquira, Boyacá, Cordillera Oriental de Colombia. Geología Colombiana, 37, 63-75.

González Partida, E., Barragán Reyes, R., \& Vazquez Escobedo, R. (1992). Distribución y Condiciones de Formación de los Minerales de Arcilla en un Campo Geotérmico. el Caso de los Humeros. Estado de Puebla. Universidad Nacional Autónoma de Mexico, Instituto de Geología, 47-53.

Gopal , K., \& Sen, S. (2008). Adsorption of a few heavy metals on natural and modified kaolinite and montmorillonite: A review. Advances in Colloid and Interface Science, 114-131.

Hanna, H., \& Somasundaran, P. (1977). Physicochemical aspects of adsorption at Solid/ Liquid Interfaces. Improved Oil Recovery by Surfactant and Polymer Flooding, D. O. Shah, R. S. Schechter, 253-274.

Hanna, H., \& Somasundaran, P. (1979). Adsorption of Sulfonates on Reservoir Rocks. Society of Petroleum Engineers of AIME, 221-232.

Hanna, H., \& Somasundaran, P. (1979). Equilibration of 
Kaolinite in Aqueous Inorganic and Surfactant Solutions! Journal of Colloids and Interface Science, 181-191.

Jabbour, G., Márquez, R., \& Guerra, I. (2009). Un modelo para la clasificación de areniscas. Ciencia e Ingeniería, 219-228.

Jaimes, M. G., Rojas, J. A., Rodríguez, M. J., Zabala, R. D.,\&Dorado, R.(2019). Protocolo experimental para la evaluación de microemulsiones que modifican la mojabilidad en el medio poroso. Aplicación a campos colombianos. Fuentes, el reventón energético, 17(2), 63-75.

Kahr, G., \& Madsen, F. (1995). Determination of the cation exchange capacity and the surface area of bentonite, illite and kaolinite by methylene blue adsorption. Applied Clay Science, 327-336.

Lobo, A., \& Riverio, M. (Septiembre de 2013). Descripción mineralógica y petrográfica de la Formación Misoa con fines de formulación óptima en Recuperación Mejorada de Petróleo. Trabajo de final para obtener el grado de Ingeniero Geólogo. Merida, Merida, Venezuela.

Ma, C., \& Eggleton, R. (1999). Cation Exchange Capacity of Kaolinite. Clays and Clays Minerals, 174-180.

Mannhardt, K., Schramm, L., \& Novosad, J. (1983). Effect of Rock Type and Brine Composition on Adsorption of Two Foam-Forming Surfactants. SPE, Petroleum Recovery Inst., 212-218.

Martin, C. A. G., \& Páez, E. M. (2017). Efeito da salinidade na tensão interfacial do sistema óleo/ agua em condições isobáricas e incremento gradual da temperatura. Revista Fuentes, 15(2), 117-124.

Martínez, N., \& Camposano, L. (2000). Caracterización química y radiométrica de secciones estratigráficas de las formaciones Barco y Mirador, San Pedro del Río, Edo. Táchira. Universidad Central de Venezuela, Ingenieria Geologica. Caracas: CONICIT - Agenda Petróleo.

Meier, L., \& Kahr, G. (1999). Determination of Cation Exchange Capacity (CEC) of Clay Minerals using the complexes of Copper(II) Ion with Triethylenetetramine and Tetraethylenepentamine. Clays and Clay Minerals, 47(3), 386-388.

Molero Díaz, M. (2006). Estudio sedimentológico de las arenas B, de la Formación Misoa, Campo Mene Grande. Trabajo Especial de Grado para optar al titulo de MAGISTER SCIENTIARIUM EN GEOLOGÍA PETROLERA. Maracaibo,
Zulia, Venezuela: Universidad del Zulia.

Molina, N. C., Guevara, D. A., \& Fernández de Ullivarri, J. (s.f.). Fisico Quimica de Suelos. Universidad Nacional de Tucuman, Cátedra de Edafología.

Muñoz Meneses , R., Muñoz Chaves, J., Mancilla, P., \& Rodríguez-Páez1, J. (2007). Caracterización Fisicoquímica de arcillas del Municipio de Guapi - Costa Pacífica Caucana (Colombia). REV. ACAD. COLOMB. CIENC, 537-544.

Nima Ramírez, F. E., Bravo Cabrejos, J. A., Mejia Santillán, M. E., \& Silva Valdivieso, D. (Julio de 2011). Caracterización mineralógica de la fracción arcillosa de vertisols de la parcela de la Universidad Nacional de Piura, San Lorenzo, Piura. (V. d. Investigación, Ed.) Revista de Investigación de Física, 14, 1-8.

Novosad, J. (1982). Surfactant Retention In Berea Sandstone Effects of Phase Behavior and Temperature. SPE. Petroleum Recovery Ins!., 962-970.

Ordoñez, J., \& García, R. F. (2015). Estudio inicial de geo-polimeros a partir de arcillas. Fuentes: El reventón energético, 13(2), 113-117.

Petroleos de Venezuela S.A. (s.f.). Código Estratigráfico de las Cuencas Petroleras de Venezuela. Recuperado el 23 de septiembre de 2015, de http://www.pdv.com/lexico/lexicoh.htm

Salager, J.-L. (2005). Recuperación Mejorada de Petróleo. Cuedernos FIRP S-357C. Merida, Merida, Venezuela: Laboratorio Formulación Interfases Reología y Procesos.

Salari,, Z., Ahmadi, M., Kharrat, R., \& Shahri, A. (2011). Experimental Studies of Cationic Surfactant Adsorption onto Carbonate Rocks. Australian Journal of Basic and Applied Sciences, 808-813.

Schramm, L., \& Marangoni, D. (2000). Surfactants and Their Solutions:Basic Principles. En L. L. Schramm, Surfactants: Fundamentals and Applications in the Petroleum Industry (págs. 3-50). United Kingdom: CAMBRIDGE UNIVERSITY PRESS.

Sircar, S. (2005). Adsorption. En The Engineering Handbook. Second Edition (pág. 14). CRC Press LLC.

Somasundaran, P., \& Fuerstenau, D. (1965). Mechanisms of Alkyl Sulfonate Adsorption at the Alumina-Water Interface. The Journal of Physical Chembtry, 90-96.

Somasundaran, P., Healy, T., \& Fuerstenau, D. (1964). Surfactant Adsorption at the Solid-Liquid Interface-Dependence of Mechanism on Chain Length. The Journal of Physical Chemistry, 3562-3566. 
Spalletti, L. A., \& Poiré, D. (2007). Diagénesis de Rocas Clásticas. La Plata, Argentina.

Srodon, J., Morgan, D., Eslinger, E., Eberl, D., \& Karlinger, M. (1986). Chemestry of Illite/ Smectite and end-member Illite. Clays and Clay Minerals, 34(4), 368-378.

Suzuki, M. (1990). Porous Adsorbents. En M. Suzuki, Adsorption Engineering. Tokio: KODANSHA LTD y ELSEVIER SCIENCE PUBLISHERS.

Toro, G. M., Herrera, J. J., Orrego, J. A., Rojas, F. A., Rueda, M. F., \& Manrique, E. J. (2018). Effect of ionic composition in water: oil interactions in adjusted brine chemistry waterflooding: preliminary results. Fuentes: El reventón energético, 16(2), 73-82.

Van Veen,, F. (s.f.). Ambientes sedimentarios de las Formaciones Mirador y Misoa del Eoceno Inferior y Medio en la Cuenca del Lago de Maracaibo. IV Congreso geológico venezolano.
Velde, B. (1977). Clays and Clays Minerals in Natural and Synthetics Systems. Amsterdam: Elsevier Scientific Publishing Company.

Wesson, L., \& Harwell, J. (2000). Surfactant Adsorption in Porous Media. En L. Schramm, Surfactants: Fundamentals and Applications in the Petroleum Industry (págs. 121158). United Kingdom: CAMBRIDGE UNIVERSITY PRESS.

Xu, Q., Vasudevan, T., \& Somasundaran, P. (1991). Adsorption of Anionic-Nonionic and Cationic-Nonionic Surfactant Mixtures on Kaolinite. Journal of Colloids and Interface Science, 528-534.

Yang, C.-Z., Jao, W.-L., \& Huang, Y.-H. (1989). The Mechanism of Adsorption and a new method to reduce surfactant loss in chemical flooding. Journal of Petroleum Science and Engineering, 97-109.

Recepción: 08 de noviembre de 2019

Aceptación: 15 de marzo de 2020 